Article

\title{
The Role of a City Council in a Place Branding Campaign: The Case of Vic in Catalonia
}

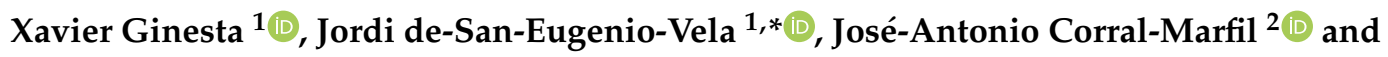 \\ Jordi Montaña ${ }^{3}$ \\ 1 Department of Communication, University of Vic-Central University of Catalonia, Sagrada Família 7, \\ 08500 Vic, Barcelona, Spain; xavier.ginesta@uvic.cat \\ 2 Department of Economics and Business, University of Vic-Central University of Catalonia, Sagrada Família \\ 7, 08500 Vic, Barcelona, Spain; joseantonio.corral@uvic.cat \\ 3 ESADE, Ramon Llull University, Av. Pedralbes 60-62, 08034 Barcelona, Spain; jordi.montana@esade.edu \\ * Correspondence: jordi.saneugenio@uvic.cat; Tel.: +34-93-886-12-22
}

Received: 11 May 2020; Accepted: 25 May 2020; Published: 28 May 2020

check for updates

\begin{abstract}
The fundamental goal of this article is to show the implications that place branding has for regional public management through a case study of the brand "Vic, a city with a human dimension" [Vic, ciutat a la mesura humana, in Catalan language], a project commissioned by the city council of Vic and carried out by the city's university (University of Vic-Central University of Catalonia). Vic is the capital of the Osona region, in the centre of Catalonia, with a population of 45,040 inhabitants. Methodologically, this research utilised 14 focus group discussions, two in-depth interviews and a survey addressed to citizens and answered by 855 people. In regards to results, the research shows that the practice of place branding transcends the traditional action areas of place marketing and place promotion, in order to be fully integrated in the region's overall management policies, that is to say, its urban governance. The article also concludes that the processes of conceptualisation and implementation of new place brands must be framed within a bottom-up approach, integrating all the stakeholders (public-private cooperation) in the decision-making process.
\end{abstract}

Keywords: place branding; city branding; public branding; urban governance; public-private cooperation; Vic; Catalonia

In memoriam Jordi Cano

\section{Introduction}

Place brands are defined based on the influence they have on people's perception. Acquiring a unique identity expressed through a brand provides recognition and differentiation in specific geographical areas, enabling them to position themselves in a way that is decisive in the preferences of citizens. In this context, the places cede the projection of their identity to a new symbolic identity managed, in part, by transforming places into brands. A place's identity is today no minor matter. Rather, it is almost a question of survival, not so much in economic terms as an essential need for identity projection in times of globalisation.

The regions, in today's world, have an increasing need to establish their identities not just for economic reasons (tourism, market doctrine and so on) but for a new demand to reinforce one's identity in a globalised world.

Some research [1-3] shows that the logic of place brand implantation has followed, in most cases, almost the same process of creating commercial brands, using its marketing and communication techniques: "In general, the implantation dynamic of place brands is essentially operative (do) and not very reflexive (why do?)" [3] (p. 732). 
However, it is well-established that the creation of place brands in all geographical levels (country, city, nation, region, destination, among others) must, necessarily, consider different approaches to those taken in the corporate sphere due to two main arguments: the need to see the brand creation process from a regional and environmental sensibility; and the public interest that is an integral part of such initiatives [4]. Likewise, the intangible dimension of a place branding strategy, that is, the emotional relationship between people and places, shows the power to transform the place identity into a sense of place feeling [3].

The main purpose of this article is to contribute to the advancement of city brand management through the study of a case that "connects" city branding research and practice [5]. The creation process of the brand "Vic, a city with a human dimension" is presented and analysed. This was carried out, at the request of the City Council of Vic, capital of the Osona region with a population of 45,040 , by the consolidated research group TRACTE (Translation, Communication and Territory) of the University of Vic-Central University of Catalonia (UVic-UCC) in 2013-2014. Hence, this research has two research objectives:

RO1: To confirm the importance of the stakeholders in giving form to the narrative of the place brands [6].

RO2: To analyse the impact that the place brands have on improving local governance-that is to say, understand public branding as a holistic exercise of governance and public management $[7,8]$.

\section{Theoretical Framework}

\subsection{The Conceptual Foundations of Place Branding}

In the specific field of place branding, the purpose of the brand, argues Anholt [2], is not exclusively to achieve economic performance, but also to achieve a good reputation for the place, which, logically, will also have an effect on its economic prosperity. The virtue of this broader vision of place branding lies, according to Anholt [9], in its flexibility, given that it is capable of marrying the forces of the market with the particular interests of human capital.

In the same vein, López-Lita and Benlloch [10] (p. 51) point out that: “The brand must serve as a basis for 'branding' the places in order to differentiate them and highlight their anthropological and cultural differences, thus transcending the initial exclusive focus on the economic dimension".

Hankinson [11] seeks to establish a conceptual model for place brands and, to do so, starts with four concepts inherent in the brand, as well as the concept of place branding, based on the relation it has with the target audience, focusing on behaviour rather than communication and on reality rather than image. Hankinson [11] goes on to point out the purpose of the brand as a means to communicate identity and, therefore, differentiation. He also mentions the role of the brand as a perceptual entity or image related to consumers' awareness, reason and emotions. Further, he mentions the brand as a value enhancer linked to place management and, finally, refers to the relational value inherent in the brand, in the sense of interpreting the brand and its personality in terms of relation to the consumer.

Zenker and Braun $[12,13]$ also point out the significance of consumer perceptions in order to define what a place brand is. The "sense of place" is the indicator of the meanings and sensations inherent in geographical spaces [3]. Hence, and following Zenker and Braun [12] (p. 3), a place brand is "a network of associations in the consumers' mind based on the visual, verbal, and behavioural expression of a place, which is embodied through the aims, communication, values, and the general culture of the place's stakeholders and the overall place design. Essential for this definition is that a brand is not in reality the communicated expression or the 'place physics', but the perception of those expressions in the mind of the target group(s)". Furthermore, and "in conformity with social identity theory, for example, the external target audience (out-group) shows a much more common and stereotypical association set with a place, while the internal target audience (in-group) has a more diverse and heterogeneous place brand perception" [12] (p. 3). 
More concretely, and based on a fundamental model of differentiation and positioning of the corporate brand, place branding pursues the following objectives [14] (p. 107): increase its attractiveness both for business investors and in order to capture and retain talent; improve its competitive position in the tourism market; foment citizen identification with their place of residence; and, finally, facilitate, in general, economic and social development.

Moreover, the purpose of branding is not merely to project and communicate a certain image and reputation beyond the place, but also to attempt to enhance the pride of residence and feeling of belonging within the local population.

Unlike the promotion of places, place branding is not an intuitive and random activity, but one with a much more integrated and strategic focus. It is directly linked to a new urban lifestyle in which visual images and myths associated with the place are important. In this context, image promotion is central to planners and policy makers. This is why the arrival of marketing and place branding is a natural consequence of a new regional governance that is very much aimed at satisfying the wishes and desires of its potential public $[8,13,15]$.

Therefore, the definitive split between the terms place promotion, place selling and place branding results from the realisation that a region has a large public potential to whom it can be addressed and many attributes and values to offer [16]. Thus, the strategies of promotion lose all validity when faced with the new logic of regional action. In this regard, Boisen, Terlouw, Groote and Couwenberg [17] distinguish between the concept of place branding and those of place promotion and place marketing: "Place branding is the most encompassing of the three [in relation to place promotion and place marketing], and that it asks the most of the organisational capacity. In order for place branding to be a meaningful instrument, it cannot be a separate policy field or an external organisational entity-and requires an even deeper integration as compared to place marketing" [17] (p. 10).

Indeed, place branding aims to implement advanced branding techniques, which, to a certain extent, entails the loss of the mercantilism and utilitarianism that is so characteristic of place promotion in order to move towards managing the places' reputation with the aim of optimising their assets. In this vein, the ultimate purpose of this practice is to obtain a favourable positioning in the world market of places by projecting an image that corresponds to the reality of the place represented, avoiding stereotypes or clichés which offer a biased view.

\subsection{Place Branding and Regional Public Management}

Consequently, the current discipline of place branding is in clear need of updating based on the degree of its impact on society. Bearing in mind the leadership role that the public administration has in the implementation of these processes, there are two concepts that limit its impact on the overall management of the territory: a) adaptations of corporate branding to res publica $[7,18]$; and b) the importance of place branding in improving governance and, even more so, spatial planning of the place $[8,19]$.

We must not forget, then, that when considering how to dovetail the place branding discipline and public management of the place, we are approaching the analysis of its political dimension, understood as urban politics [20,21]. However, as Lucarelli [20] explains, approaching place branding from a political perspective cannot be done in a reductionist manner. Instead, it must be approached in a broader way with the public administration and with a focus on all the different agents involved. Lucarelli [20] (p. 12) concludes that place branding is "a processual hybrid policy in which the public and the private, economics and politics, the market and the polis, are blurred and co-emerge as a process in a relational and interactive manner".

This, therefore, shuns the political strategy that usually dominates public management and that, in the case of Spain, has characterised the way in which public policies have been planned. Moreover, those linked to place promotion have often ended up being reduced to a logo or slogan with no real connection to the public management of the place [22]. Gaggiotti, Gheng and Yunak [23] note that the process of defining a city brand cannot solely be implemented by the city government as the only agent, 
but rather requires approaching place branding from a perspective of urban planning, management and dialogue with all the stakeholders; that is, all residents.

In this vein, a political dimension of place branding also needs to take into account that residents should take an active role in a place branding process. This means that, although residents can play a role in this process "as an integral part of the place brand through their characteristics and behaviour" and "as ambassadors for their place brand who grant credibility to any communicated message" [24] (p. 18), "by far the biggest challenge for place brand managers is the role of residents as citizens, as they could 'make or break' the whole place branding effort" [24] (p. 23). Braun, Kavaratzis and Zenker conclude that "It is as citizens that residents legitimise the place brand efforts and actually 'finance' most of the efforts and expenses involved in place branding" [24] (p. 23).

Unfortunately, however, there still remains a conception of place branding from a much more tactical and operational than strategic perspective, which makes it more difficult for the public administration to implement the holistic conception of this practice. This is clear from the research carried out with consultants of place branding and place management in the United Kingdom and Ireland by Noronha, Coca-Stefaniak and Morrison [25]. After 15 in-depth interviews with professionals of the sector, they concluded that "The strategic potential of place branding is negatively affected by a focus on operational thinking, which hinders innovation towards more holistic approaches to place management" [25] (p. 91).

\section{Background Context}

The city of Vic is located at the confluence of the rivers Mèder and Gurri, $70 \mathrm{~km}$ north of Barcelona, in the middle of a plain surrounded by mountains, where fog is the most characteristic climatic feature. Its origins date back to the Roman period, from which there are clear settlements. It was particularly important during the Middle Ages, the county seat and one of the most important bishoprics in medieval Catalonia [26]. It has never lost the uniqueness and political importance that it gained in the medieval era, and today it has become one of the most important commercial centres in central Catalonia. This fact was reinforced by the recovery of its university in 1997, now named University of Vic-Central University of Catalonia, which has medieval origins and was formally established in the Renaissance (1599), but which was closed along with other higher education institutions after the Nueva Planta Decrees (Decrets de Nova Planta in Catalan) of Philip V at the beginning of the eighteenth century [27].

In Vic's historic centre, there are a number of places of historic and artistic interest. The spacious Plaça Major (Main Square) is the busiest part of the city. It is bordered by buildings of different styles, but built on arched porches that give it a unified look. The other main architectural ensembles are: Vic Cathedral (Catedral de Sant Pere Apòstol), decorated by the muralist Josep Maria Sert; the Santa Creu Hospital; the Roman Temple and the Montcada Castle; and the Casa de la Ciutat (City Hall). Vic's Episcopal Museum - declared to be of national interest by the Government of Catalonia-houses masterpieces of medieval Catalan sacred art, including valuable paintings and sculptures from the Gothic and Romanesque periods. The other three museums in Vic are the Leather Art Museum, the Museum of Sant Antoni M. Claret and the Balmes Museum [28].

The city of Vic is the capital of the Osona region, within the autonomous community of Catalonia, in Spain. Currently, according to the Statistical Institute of Catalonia [29], Vic has a population of $45,040,11,143$ of whom are of foreign origin. In fact, the various migratory waves that the city of Vic has hosted since the early 1990s explain much of the municipality's challenges in the twenty-first century [30], as well as creating a major political controversy that led to the emergence of one of the first openly xenophobic political parties in democratic Spain: Plataforma per Catalunya (Platform for Catalonia) (PxC) [31]. Table 1 shows some of the main data about the city. 
Table 1. Main population and macroeconomic data of the city of Vic [29].

\begin{tabular}{cc}
\hline Population & 45,040 \\
\hline GDP (million euros) & 1827.2 \\
\hline GDP per capita (thousand euros) & 41.5 \\
\hline Household income per capita (thousand euros) & 16.5 \\
\hline Registered unemployed & 2364.2 \\
\hline
\end{tabular}

The cultural influence of the Church [32,33], as well as an industry strongly marked by leather and meat [26], have defined the city's positioning for centuries. However, as part of the research that led to the new Vic brand, the initial diagnosis of the city of Vic branding policy carried out since the beginning of the democratic period, shows that there is a high volatility of brands that correspond with political mandates. It is therefore clear that, depending on the councillor in charge of the cultural and economic policy of the city, the brand and its positioning have varied. In total, there have been eight attempts to create a lasting brand for the city: "Vich (In old Catalan and during the Francoist regime (1939-1975) the city was named "Vich".), city of touristic interest, monumental complex and excursion centre (in Spanish)", in 1973; "Vic, city of touristic interest, monumental complex and excursion centre (in Catalan)", in 1980; "Vic, a city with a human dimension", in 1982; "Vic, the roots and progress", in 1988; "Welcome" (with the word Vic included in an adapted Catalan word for welcome: Benvicgut)", in 1994; "Vic and you", in 1999; "Vic, city of ... ", in 2004; and, finally, "Vic Moves", in 2009.

This shows that the inhabitants of the city of Vic have, in general, very little brand recall, with the 2004 campaign of "Vic, city of ... " being the most successful one according to the results of the field work carried out, as will be seen in Section 5 of this article.

\section{Materials and Methods}

This article is the fruit of presenting, scientifically, the result of applied research that the investigation team of the UVic-UCC Translation, Communication and Territory (TRACTE) research group conducted to design and conceptualise the city of Vic brand.

This research began with an initial diagnosis of the city's brand policy over the last forty years, followed by field work on the conceptualisation of the current brand, based on three research techniques, which forms a methodological triangulation. These techniques, quantitative and qualitative, aimed to integrate the holistic perspective of residents in the place brand creation process because, as Braun, Kavaratzis and Zenker [24] (p. 23) highlight, "participation is absolutely necessary for a successful place branding strategy".

Qualitatively, the research focused on 14 focus group discussions (Table 2). All the focus groups followed the same questionnaire (Table 3), and each focus group discussion was transcribed in order to detect common perceptions and items answered by its participants, as well as to compare them with all the answers of the focus group at the end of the field work. The focus groups were complemented with two semi-standardised interviews (Table 4), where the interviewer possesses a number of items or topics to cover, but does not follow sensu stricto a prefabricated questionnaire [34] (p. 253). These two interviews served to frame the complexity of the focus group results and delve more deeply into urban planning and the city's tourism brand, two crucial aspects in any process of city branding $[19,35]$.

Quantitatively, a survey consisting of ten questions (Table 5), eight open and two closed, was used. In order to engage residents in this process, as Braun, Kavaratzis and Zenker [24] (p. 24) point out, "a survey on the residents' views and evaluations can be thought of as a participatory tool, or at least as an indication of good intentions". 
Table 2. List of focus group discussions carried out.

\begin{tabular}{cc}
\hline Name of Group & Number of Participants \\
\hline Cultural entities and centres & 14 \\
\hline Schools and the University of Vic-Central University of Catalonia & 10 \\
\hline Sports and youth organisations & 13 \\
\hline Organisations of traders, street vendors and fair workers & 11 \\
\hline Children & 18 \\
\hline Seniors & 13 \\
\hline Urbanism and the environment & 10 \\
\hline Health network entities and social entities & 10 \\
\hline Coexistence and security & 11 \\
\hline Tour agents and business owners & 11 \\
\hline Media & 9 \\
\hline Catering and the gastronomy sector & 10 \\
\hline Eolitical parties, ex-mayors and ex-councillors & 9 \\
\hline Entities from other towns of the region & 15 \\
\hline
\end{tabular}

Table 3. Focus group questionnaire.

\begin{tabular}{|c|c|}
\hline \multicolumn{2}{|c|}{ Participants Were Asked the Following Questions: } \\
\hline \multicolumn{2}{|c|}{ What is a place brand and what do you expect from Vic's city brand? } \\
\hline \multicolumn{2}{|c|}{ What are the main differences between a commercial band and a city brand? } \\
\hline \multicolumn{2}{|c|}{ What are the main objectives of a city brand? } \\
\hline \multicolumn{2}{|c|}{ What values of the residents would you transfer to the new brand? } \\
\hline \multicolumn{2}{|c|}{ What are the main positioning assets of the city? } \\
\hline \multicolumn{2}{|c|}{ What do you remember from Vic's previous city brands? } \\
\hline \multicolumn{2}{|c|}{ Do you think that a city brand will be useful to revitalise your city? } \\
\hline \multicolumn{2}{|c|}{ How would you engage residents to use a new city brand? } \\
\hline \multicolumn{2}{|c|}{ Do you think that a new city brand should be a used only in touristic campaigns or wit } \\
\hline \multicolumn{2}{|c|}{ Table 4 . List of semi-standardised interviews. } \\
\hline Interviewee 1 & Architect and city planner \\
\hline Culture and tou & Culture and tourism personnel at the City Council of Vic \\
\hline \multicolumn{2}{|c|}{ Table 5. Structure of the survey questionnaire. } \\
\hline Question & Typology of Answer \\
\hline What do you like most about the city of Vic? & Open \\
\hline What do you dislike about the city? & Open \\
\hline $\begin{array}{l}\text { Can you describe the main virtues and shortcomings of the } \\
\text { residents of Vic? }\end{array}$ & Open \\
\hline What do you think foreigners think of Vic? & Open \\
\hline What colour would you associate with the idea of Vic? & Open \\
\hline What icon from Vic would you take to a desert island? & Open \\
\hline
\end{tabular}


Table 5. Cont.

\begin{tabular}{|c|c|}
\hline Question & Typology of Answer \\
\hline Which asset generates in you the greatest sense of belonging? & $\begin{array}{l}\text { Closed answer: Episcopal Museum of Vic; Vic University; } \\
\text { L'Atlàntida, the Performing Arts Center and the School of } \\
\text { Music; the work of the painter Josep M. Sert; the historic } \\
\text { centre; La plaça Major (Main square). }\end{array}$ \\
\hline $\begin{array}{l}\text { Can you order, according to your criteria, which of these } \\
\text { values best define the city? }\end{array}$ & $\begin{array}{l}\text { Closed answer: art and culture, nature, tranquillity, quality } \\
\text { of life, tradition, the medieval past, other. }\end{array}$ \\
\hline How would you imagine the city in ten years? & Open \\
\hline $\begin{array}{c}\text { Do you have any other comments that you think would be } \\
\text { interesting to include in this research? }\end{array}$ & Open \\
\hline
\end{tabular}

The survey was available to the public on the Internet, on the website www.vic.cat/marcavic, to ensure that all Vic inhabitants had access to it, and this web link was promoted in forty events in Vic organised by the City Council. In this regard, no type of criteria to select the sample was used; instead, the website tried to reach the entire population: residents in the city of Vic. The survey was designed using a standard monthly plan provided by the platform SurveyMonkey, which was contracted by Vic City Council, and data analysis processing and codification was done using MS Excel.

The success was considerable, considering that during the 2013-2014 academic year 855 replies were collected. Apart from two closed questions and the last one-which asked citizens if they wanted to add anything else to the rest of the analysed dimensions of the city-the processing of data from this survey led to the establishment of variables for each of the other open questions, according to respondents. For each of the questions we tried to work on a list of between ten and twelve empirical variables (or indicators) understood as "those that represent aspects of these dimensions directly measurable and/or observable" [36] (p. 60).

\section{Results: The Creation of "Vic, a City with a Human Dimension"}

In this section we will refer, in a linear fashion, to the results of the applied research that was conducted during the 2013-2014 academic year and which enabled the creation of the brand "Vic, a city with a human dimension". It was presented during the Mercat del Ram (Palm Market) on 24 March 2015, in the Atlántida Auditorium of Vic, and was implemented during the municipal mandate of 2015-2019 that began two months later. The explanation of how we got here is summed up in three subsections: the analysis of the tangible assets of the city (Section 5.1), of the intangible assets (Section 5.2) and, finally, the design of a desired positioning (Section 5.3).

\subsection{Tangible Vic}

For the inhabitants of Vic, the city has a clear image: that which comprises the historic centre, with the Plaça Major (main square) and cathedral as the primary symbols. In this regard, Vic's architectural heritage is one of its most important assets, something which the inhabitants of Vic are particularly proud of, as can be seen in Table 6.

Another aspect that Vic inhabitants highlight is the city's gastronomy, which includes the production of cold meats and pork derivatives [37]. The meat industry is emphasised by some participants in the discussion groups as an important symbol of identity, while another basic socioeconomic aspect of Vic is the fact that it is a university city. As is reflected in Table 6, Vic University is something that differentiates it from other medium-sized cities of Catalonia. In fact, the UVic-UCC is the only university in Catalonia that is not a provincial capital (Barcelona, Girona, Lleida and Tarragona).

To the question "what do you dislike about the city?", the respondents also showed a consensus, saying that the city has, in general, "a bad climate". In this regard, the periods of fog that the city experiences during the winter are a symbol of identity that is inevitably associated with the story of the city. 
The relation between Vic and its county (Osona) was also discussed. All those who answered the survey and the participants in the focus groups agreed that the brand should play a crucial role in the relations between the city and its main municipalities. Vic is the nerve centre of a county, Osona, that generally has its capital as a services and logistic centre. This is why many focus group participants emphasised "the network" as a notion that defined the city.

Table 6. Assets of the city that generate the greatest sense of belonging (in \% based on survey responses). Source: Elaborated by the authors from the Marca Vic survey.

\begin{tabular}{cc}
\hline Asset & \% of Acceptance \\
\hline Episcopal Museum of Vic & 35.7 \\
\hline Vic University & 50.2 \\
\hline L'Atlàntida, the Performing Arts Centre and the School of Music & 40.3 \\
\hline The work of the painter Josep M. Sert & 23.4 \\
\hline The historic centre & 80.0 \\
\hline La plaça Major (Main square) & 83.4 \\
\hline
\end{tabular}

In fact, this network can be seen in three main services that Vic offers: commercially, Vic acts as a hub, an operational centre; educationally, there is a complete circuit from kindergarten to university for those who do not want to move from Vic during their education; and with regards to health, the network created by the Vic Hospital Consortium (CHV) is a model of health management in Catalonia.

\subsection{Intangible Vic}

The inhabitants of Vic feel very proud of their "patriotism" and "hardworking" nature. At the same time, and to a lesser degree, the field work reveals other attributes of the people of Vic like "honesty", "prudence" and "solidarity".

However, the main shortcoming that the survey respondents and focus group participants attribute to Vic is its "conservative" and "closed character". In this regard, the brand needs to loosen this connotation of being closed. Focusing on the results of the survey, to the question that refers to the values of the city, most of the 855 respondents consider that Vic is associated with a notable artistic-cultural (331) and traditional (313) impulse.

In fact, the people of Vic emphasise that the city is not dubbed "racist" as a result of the emergence of Platform for Catalonia (PxC), a far-right party with a xenophobic ideology led by Josep Anglada. Anglada was in the city council in 2003, when he entered for the first time as councillor, until 2019, when he ceased being a representative in the council. Rather, the focus group linked to schools and Vic University was particularly interested in mentioning the "educational" and "integrating" character of Vic.

The palette of colours used by citizens to depict their city was also analysed. The respondents and representatives of the focus group discussions were clear: reds and greens were their favourite hues, and red dominated. This may be due, among other things, to the fact that the collective imaginary of Vic inhabitants has made red the colour of many of the city's entities: the roller hockey club, the football club, the iconography of popular festivals and, also, its university.

\subsection{The Desired Positioning and the Brand's Design}

After analysing the city's tangible and intangible assets, the research team listed a number of considerations so that the UMedia agency, which is also a member of UVic-UCC, could come up with a new $\log$ (Figure 1 ) of the new city brand.

The rest of this section will describe the desired positioning, which is the result of the field work and embodied in Figure 1. 
First, at the brand design level, the Vic brand wishes to be integrative, representing not only the city but also the region it is an integral part of: Osona. Second, the brand should be inclusive. At certain times during the fieldwork (see Sections 5.1 and 5.2), the concept of "inclusive city" regarding the multicultural character of Vic appears, which contrasts with the positioning that the city has had in certain media due to the rise of the far-right party PxC.

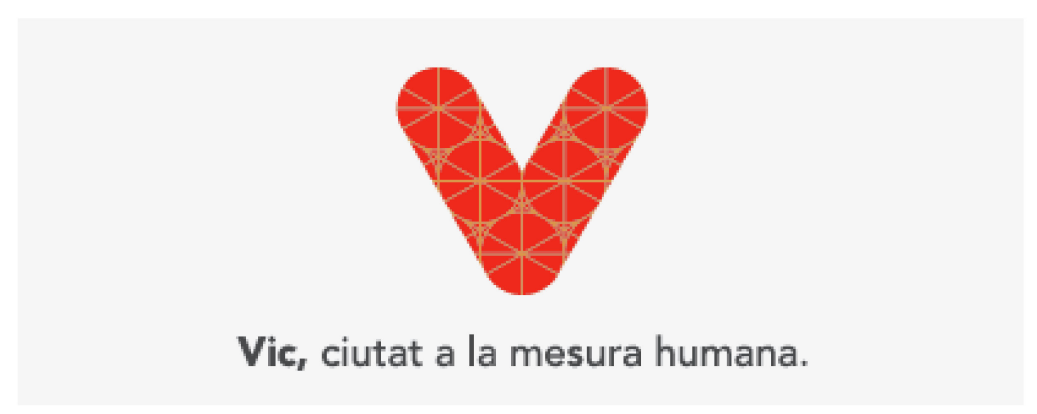

Figure 1. Logo and slogan (in Catalan) of the new Vic brand: "Vic, a city with a human dimension". Source: Reproduced with permission of the author (Vic City Council, 2020).

Third, the brand should strike a balance between tradition and modernity. Vic citizens see their city as authentic, but they also wish to show a certain degree of openness to the world; to avoid the best-known slogan of all: "Vic, the city of the saints", which comes from Miquel Llor's novel Laura a la ciutat dels Sants [Laura in the city of saints], published in 1931 and which reflected the most rural and catholic Vic of the first three decades of the twentieth century.

Fourth, the brand should have a strong predominance of artistic (Josep M. Sert, as the great contemporary painter), cultural (Mercat de Música Viva—Live Music Market, the Performing Arts Centre l'Atlàntida, Mercat del Ram, among others) and architectural assets (such as the Main Square, the Cathedral and the Roman Temple) in the collective imagination. The people of Vic are proud of their history and of what their historic centre represents.

Finally, as highlighted in the two previous points, the brand must be based on the idea of "network", which relates to the commercial attraction of Vic with respect to the other localities of the region (it has a market every Tuesday and Saturday), to its authentic educational model that has enabled the integration of different immigrant communities and avoided the creation of ghettos [30], and, finally, to its health service network from Vic to the rest of the region, through two hospitals linked to the University of Vic and the rest of the primary healthcare centres.

\section{Discussion}

In the current context, cities cannot afford to ignore the fact that they are competing in a global market of tourists and investors, and those best positioned in the collective imagination of their citizens will be those that maintain a competitive edge [3,4,12]. Having a solid brand, adapted to today's liquid society, contributes decisively to improving competitiveness in today's global world.

However, historically the process of creating city brands had taken place exclusively in laboratories of graphic design studios, disregarding the everyday reflections that can only be discovered by listening to residents [24]. The success of the Barcelona brand after the 1992 Olympics shows that city brands are likely to consolidate only if, as Hankinson [11] points out, the values they encompass are shared by a diverse public, if each one can take a piece of the brand to identify with, to find meaningful aspects of their individual collective identity. Post-Olympic Barcelona was this: everybody praises it, but everyone conceives it differently. To date, in the first ranking of city brands compiled and published by The Guardian, it was the top-ranked Spanish city in sixth place. Madrid was twelfth [38].

Reflection on the success of the capital of Catalonia's brand, conceived through cooperation between private agents and the public administration, brings us to our subject of study, the brand 
of an inland regional capital: the city of Vic. During its recent history, Vic has attempted more than once to create a brand. Indeed, out of all the attempts mentioned in this article, only the campaign "Vic, city of..." is considered by the field work participants. However, the rest of the attempts have been unsuccessful due to a lack of connection between those who commissioned and designed it and what citizens sought. As a result, the emotional connection that Hankinson [11] demands between the brand and stakeholders had not occurred: neither the residents nor the voters played their roles of brand ambassadors, nor were their different voices included in those processes [24]. Instead, what occurred was what Gaggiotti, Cheng and Yunak [23] (p. 122) criticised when they pointed out that, in many cases, the public administration had implemented the brand "acting alone". Nevertheless, the design of a new brand in 2015- "Vic, a city with a human dimension" - is based on a totally different premise: listening to all the stakeholders, both public and private, who live in the city and then create their graphic image.

In this regard, and according to our first research objective (RO1), the meetings with the different entities and organisations of the city (14 in total)—from schools, restaurants, hotels and security forces to neighbourhood associations, tradespeople and architectural firms-played a crucial role in the bottom-up process of designing the brand. In other words, the stakeholders were involved in a co-creation process of the city brand $[3,39]$. "The stones speak", recalled an architect in one of the semi-standardised interviews of this study designed to capture the essence of the city and contextualise the more quantitative results. Indeed, we could say that the search for a soul that can become a point of reference for most citizens-a common starting point to begin to build a robust and lasting collective imaginary-is one of the main goals of a place brand. In fact, as San Eugenio [3] points out, without soul, brands do not last. Furthermore, Green, Grace and Perkins [39] (p. 349) remind us "how [tangible and intangible] urban reminders, the arts, and residential behaviour emit symbolic messages in highly interrelated ways that see these elements propel the interconnected meaning-making processes enveloping city brands", and understand that "case study research also helps to examine the interplay of socially constructed city elements, more personalized city narratives, intentional city branding efforts, various stakeholders, and sociocultural factors within particular contexts" [39] (p. 366).

Apart from this participatory process that involved the city's public and private agents, another element that makes the new brand a shared and city project is the leadership of a municipal government team that, at the beginning, sought the consensus of all the political forces on this project. Following our second research objective (RO2), only with the certainty that all the municipal groups understand the need to advance towards a global brand for this capital, one that will last a long time, can we prevent these brands from becoming the result of one term of office. Strategic vision in brand conception is key to successful implementation [15], as well as being one of the most important challenges that the researchers and political authorities involved faced: without political consensus, the temptation to build a brand according to the electoral tactic of each municipal group is a recurring danger in these types of actions. This is shown by other studies in similar contexts $[22,23,40]$. In this study, a political consensus was created during the field research between 2013 and 2014, with regular interventions of the research team in the informative commissions of the city council. Hence, most representatives that took part in the municipal elections on 24 May 2015 had taken part in those commissions and were following the project before the elections.

Vic City Council was not only the driving force behind the brand in 2015. Rather, the new configuration of the municipal representatives that resulted from the 2015 municipal elections took over the project and led its deployment in the city. As interviewee 2 explained: "This deployment was embodied in the placing of the logo and slogan on all official communications (Figure 2), the labelling of urban spaces and parking areas (Figure 3) and the definitive incorporation of 'Vic, a city with a human dimension' as a slogan of any municipal campaign (of economic promotion, environment, civility, equality and so on)". In this way, during the 2015-2016 term of office, the brand was already incorporated in a global and integrated way in the collective imaginary of the city. 


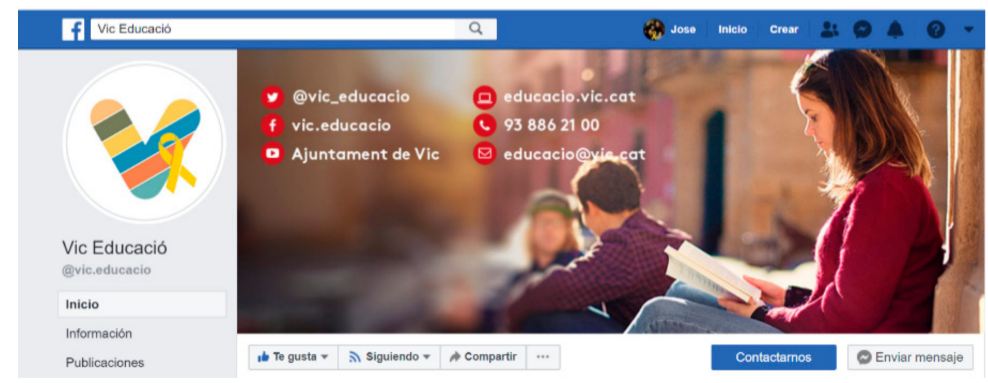

(a)

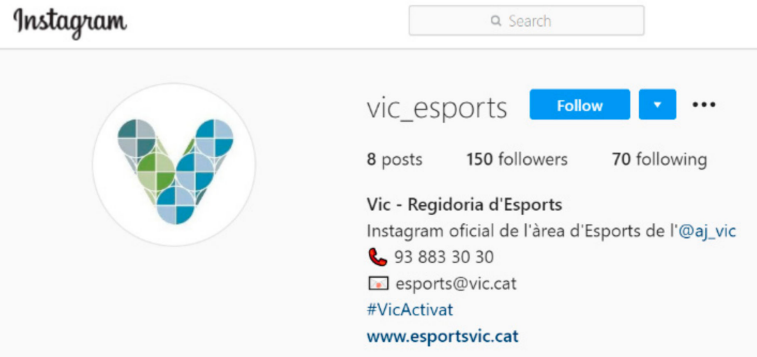

(b)

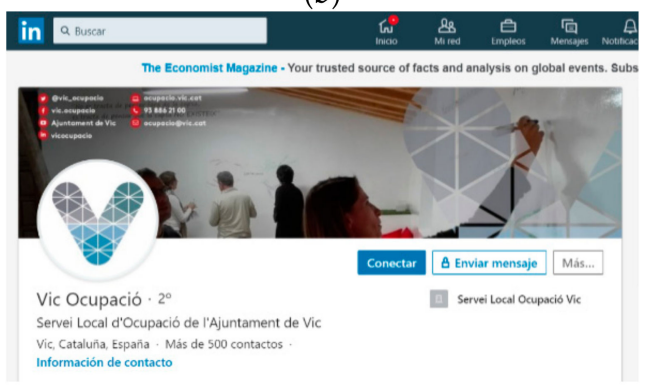

(c)

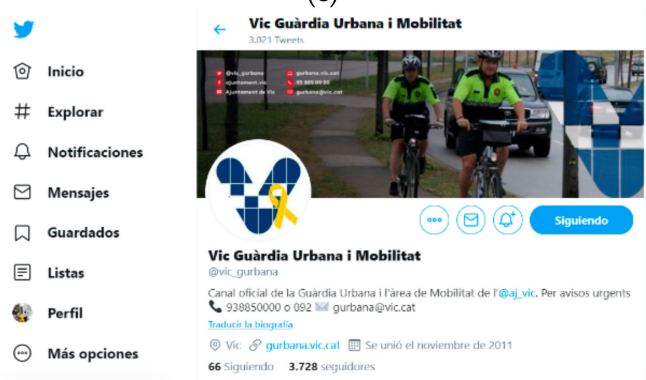

(d)
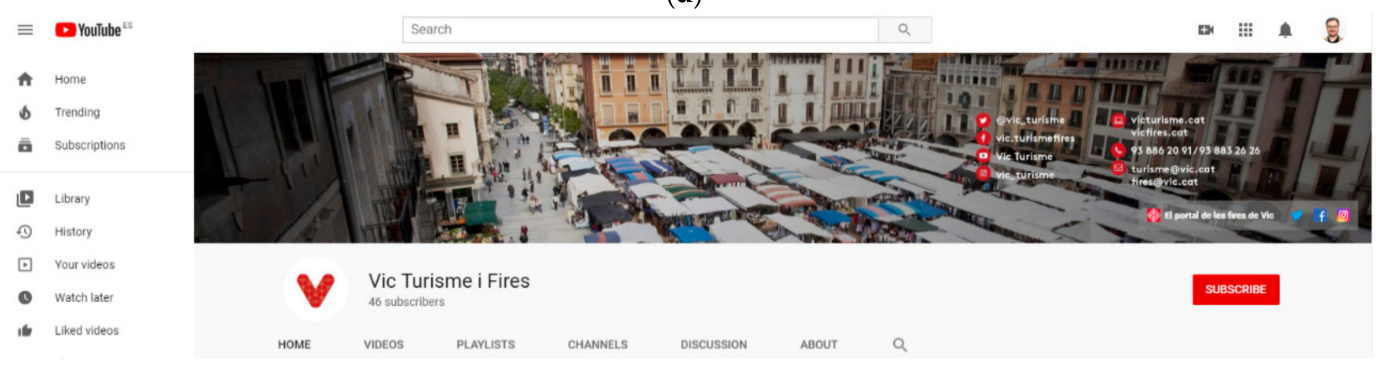

$a$

(1): 8

(e)

Figure 2. Profile of services of Vic City Council in social networks: (a) Facebook (Education); (b) Instagram (Sports); (c) LinkedIn (Employment); (d) Twitter (Police); (e) YouTube (Tourism). Source: Reproduced with permission of the author (Vic City Council, 2020). 


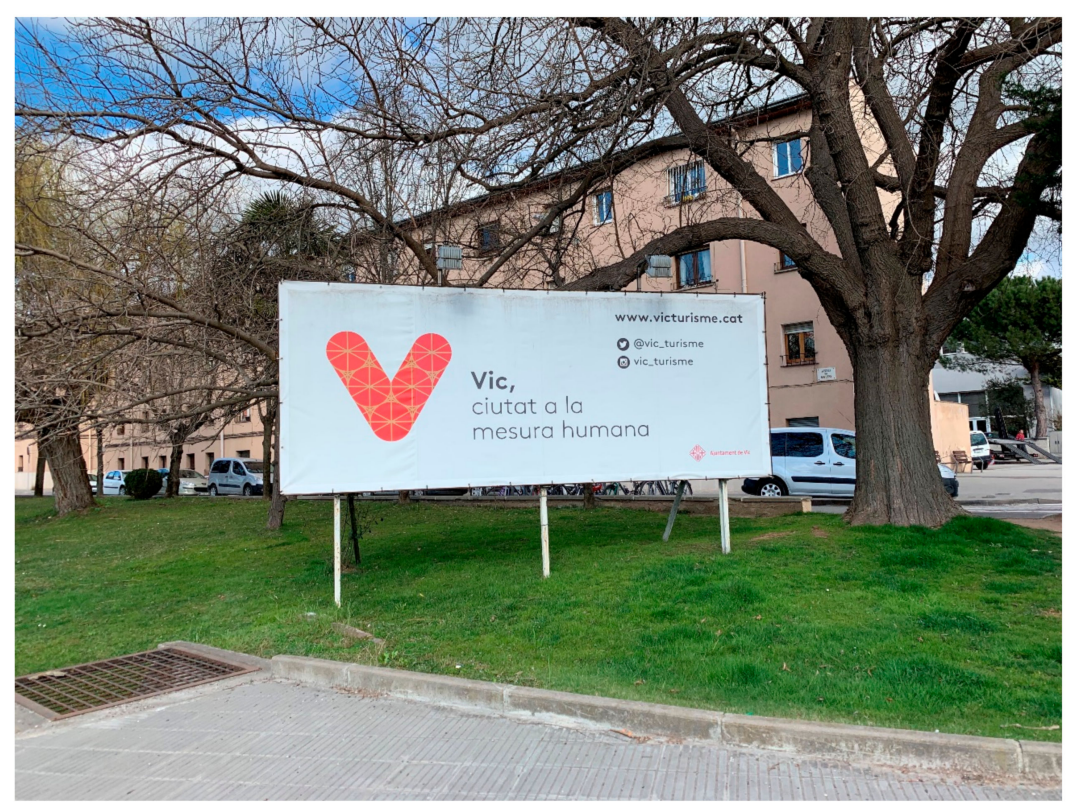

Figure 3. The new Vic brand was used in different off-line communication actions, such as the tourist campaign murals on the road, as is shown in this picture. Source: The authors.

Nevertheless, the brand's deployment was not fast due to the three months stand-by period between the municipal elections and the configuration of the new city council that had to lead the implementation plan. In this regard, municipal elections usually slow down those unfinished projects when they are called. However, previous political consensus allowed new representatives to start the implementation plan in September 2015 and to use the brand as a city umbrella brand [13] with the purpose of creating a common narrative for all the residents, as well as using it in the official communication campaigns and support: off-line (basically, murals on the road) and online (11 Twitter accounts, 8 Facebook accounts, 2 Instagram accounts, 2 YouTube channels and 1 LinkedIn account).

Finally, we must not forget the invigorating role of Vic University in this whole process. Vic City Council entrusted the process of design and conceptualisation of the brand to its university, recognising the important role that the institution plays in the region's economic and social promotion, and the need to create connections between the government and academia that help to overcome the gap that exists between basic research and the transference of that knowledge.

For this reason, this project joins the rest of the actions that have made this higher education institution one of the main assets of the Osona region. As Casulleras [41] (p. 40) explains: "In Osona alone, then, there are 1331 jobs directly or indirectly related to the UVic. Given that the number of social security affiliates was, in June 2018, 70,068 people, we can state that the UVic is responsible for $1.8 \%$ of the region's total employment". Further, continues Casulleras [41] (p. 41): "The wealth generated directly or indirectly by the UVic represents $2.365 \%$ of Osona's GDP".

\section{Conclusions}

The brand "Vic, a city with a human dimension" was presented in the auditorium of Vic's l'Atlàntida during the Mercat de Ram in 2015, one of the city's most important markets, as it provides a link with the historical livestock tradition of the Osona region since the Middle Ages [42]. The brand, with its subsequent implementation during the 2015-2019 municipal term, can be seen to have fulfilled its main function: creating a nexus that unites the city's whole story. Specifically, by placing citizens and quality of life ("with a human dimension") at the centre of the city's policies and collective imagination. From this project, we can draw a number of conclusions that can also guide future research.

First, in the design and conceptualisation of place brands it is not always necessary to consider the brands ex novo; analysis of what has previously been undertaken can be used as a perfectly viable 
starting and finishing point. Brands are not a unique device of each creator, but rather a community tool whereby its identity is shaped by the interests of all its users [3]. In fact, the design of this brand connects us with the only one that, out of all previous ones, was widely remembered by the population: "Vic, city of...". Even in the various exceptions of this campaign, which dates back to 2004, the slogan "with a human dimension" was also present as one of its variants. Thus the current brand of 2015 is a revised edition of the campaign of ten years ago, which was the one that generated the greatest consensus among the population.

Second, it was shown that a place brand must be based on in-depth knowledge of the society in question. The bottom-up creation processes, based on working with the target groups and private-public cooperation, help to build much more precise arguments that can encompass a certain collective imaginary. In this process, it was shown that, for those who have participated in various focus group discussions and semi-standardised interviews, the brand becomes something that helps to manage the identity and urban governance of the place [8]. That is, identity is a determining factor for a place brand [43].

Finally, this project also leads us to consider place branding and its impact on the area of public management. As a result, place branding should be seen as an essentially political act. However, it is one that becomes a meeting point between market interests, the public administration and citizens, which in turn becomes a key element of the city's policy of economic promotion and social revitalisation [20].

In this way, Vic City Council presented a city umbrella brand with the purpose of bringing together all the sectorial campaigns and create a common narrative for all the residents. That is to say, creating a brand in order to share "values in the place brand communication by all target groups" [13] (p. 280). The public administration cannot, therefore, cease being a driving force for the place's revitalisation, based on bottom-up work structures elaborating the new brand. In this way, it managed to draw what can also be considered as a strategic plan for future action and for all municipal services. Public branding, therefore, is not a policy that should be confined exclusively to institutional communications of the public administration. It transcends the merely promotional, being something much closer to an exercise of good governance: due to its complexity, its holistic vision of public policies, the need to define and execute strategic plans and, of course, in the final communication with the stakeholders.

Author Contributions: Conceptualisation, J.d.-S.-E.-V.; methodology, J.d.-S.-E.-V.; research, J.d.-S.-E.-V., X.G. and J.-A.C.-M.; data curation, J.d.-S.-E.-V., X.G. and J.-A.C.-M.; resources J.d.-S.-E.-V., X.G. and J.M.; writing-original draft preparation, J.d.-S.-E.-V.; writing-review and editing, J.d.-S.-E.-V., X.G. and J.-A.C.-M.; supervision, J.d.-S.-E.-V. and J.M.; project administration, J.d.-S.-E.-V. and X.G.; funding acquisition, J.d.-S.-E.-V., X.G. and J.M. All authors have read and agreed to the published version of the manuscript.

Funding: This research was funded by Vic City Council and the University of Vic-Central University of Catalonia.

Acknowledgments: The authors would like to thank Ada Sanuy for providing technical support and UMedia for designing the logo of the new Vic brand.

Conflicts of Interest: The authors declare no conflict of interest.

\section{References}

1. Govers, R.; Go, F. Place Branding: Glocal, Virtual and Physical Identities, Constructed, Imagined and Experienced; Palgrave-Macmillan: Basingstoke, UK, 2009.

2. Anholt, S. Places: Identity, Image and Reputation; Palgrave-Macmillan: Basingstoke, UK, 2010.

3. San Eugenio, J. La transformació de territoris en marques: El Reconeixement i la Diferenciació D'identitats Espacials en Temps Postmoderns. Un Estat de la Qüestió. Ph.D. Thesis, Pompeu Fabra University, Barcelona, Spain, 2011.

4. San Eugenio, J. Teoria y Métodos Para Marcas de Territorio; UOC: Barcelona, Spain, 2012.

5. Green, A.; Grace, D.; Perkins, H. City branding research and practice: An integrative review. J. Brand Manag. 2016, 23, 252-272. [CrossRef] 
6. Schmeltz, L.; Kjeldsen, A.K. Co-creating polyphony or cacophony? A case study of a public organization's brand co-creation process and the challenge of orchestrating multiple internal voices. J. Brand Manag. 2019, 26, 304-316. [CrossRef]

7. Eshuis, J.; Braun, E.; Klijn, E.H. Place Marketing as Governance Strategy: An Assessment of Obstacles in Place Marketing and Their Effects on Attracting Target Groups. Public Adm. Rev. 2013, 73, 507-516. [CrossRef]

8. Eshuis, J.; Edwards, A. Branding the City: The Democratic Legitimacy of a New Mode of Governance. Urban Stud. 2013, 50, 1066-1082. [CrossRef]

9. Anholt, S. Competitive Identity; Palgrave-Macmillan: Basingstoke, UK, 2007.

10. López-Lita, R.; Benlloch, M.T. Necesitamos marcas territorio? Téc. Econ. 2006, 175, 50-52.

11. Hankinson, G. Relational network brands: Towards a conceptual model of place brands. J. Vacat. Mark. 2004, 10, 109-121. [CrossRef]

12. Zenker, S.; Braun, E. Branding a City: A Conceptual Approach for Place Branding and Place Brand Management. In Proceedings of the 39th EMAC Annual Conference 2010, Frederiksberg, Denmark, 1-4 June 2010.

13. Zenker, S.; Braun, E. Questioning a “one size fits all” city brand: Developing a branded house strategy for place brand management. J. Place Manag. Dev. 2017, 10, 270-287. [CrossRef]

14. Fernández-Cavia, J. Ciudades, regiones y países como marcas: Luces y sombras del place branding. In Manual de Comunicación Turística: De la Formación a la Persuasión, de la Promoción a la Emoción; San Eugenio, J., Ed.; Documenta Universitaria: Barcelona, Spain, 2011; pp. 103-113.

15. Kavaratzis, M. Place branding: A review of trends and conceptual models. Mark. Rev. 2005, 5, 329-342. [CrossRef]

16. Ruiz, E.C.; De la Cruz, E.R.R.; Vázquez, F.J.C. Sustainable Tourism and Residents' Perception towards the Brand: The Case of Malaga (Spain). Sustainability 2019, 11, 292. [CrossRef]

17. Boisen, M.; Terlouw, K.; Groote, P.; Couwenberg, O. Reframing place promotion, place marketing, and place branding-moving beyond conceptual confusion. Cities 2018, 80, 4-11. [CrossRef]

18. Eshuis, J.; Klijn, E.H.; Braun, E. Place marketing and citizen participation: Branding as strategy to address the emotional dimension of policy making? Int. Rev. Adm. Sci. 2014, 80, 151-171. [CrossRef]

19. Oliveira, E.H. Place branding in strategic spatial planning. J. Place Manag. Dev. 2015, 8, 23-50. [CrossRef]

20. Lucarelli, A. Place branding as urban policy: The (im) political place branding. Cities 2018, 80, $12-21$. [CrossRef]

21. Kavaratzis, M. Place branding: Are we any wiser? Cities 2018, 80, 61-63. [CrossRef]

22. San Eugenio, J.; Ginesta, X.; Kavaratzis, M. The critical role of stakeholder engagement in a place branding strategy: A case study of the Empordà brand. Eur. Plan. Stud. 2019. [CrossRef]

23. Gaggiotti, H.; Cheng, P.; Yunak, O. City brand management (CBM): The case of Kazakhstan. Place Brand. Public Dipl. 2008, 4, 115-123. [CrossRef]

24. Braun, E.; Kavaratzis, M.; Zenker, S. My city-my brand: The different roles of residents in place branding. J. Place Manag. Dev. 2013, 6, 18-28. [CrossRef]

25. De Noronha, I.; Coca-Stefaniak, A.; Morrison, A. Confused branding? An exploratory study of place branding practices among place management professionals. Cities 2017, 66, 91-98. [CrossRef]

26. Pascual, V. Vic: Una Ciutat en el Decurs de la Historia; Publicacions de l'Abadia de Montserrat: Barcelona, Spain, 1988.

27. Torrents, R. La Meva Aposta per la Universitat: Una Història per al Futur; Eumo Editorial: Vic, Spain, 2017.

28. Corral-Marfil, J.A. La implantación del Sistema Español de Calidad Turística en Destinos (SICTED): Un caso práctico de gestión de destinos. TURYDES 2012, 5, 28.

29. Idescat (Statistical Institute of Catalonia). The Municipality in Figures-Osona-Vic. Available online: https://www.idescat.cat/emex/?id=082981\&utm_campaign=home\&utm_medium=cercador\&utm_ source=territori\&lang=en (accessed on 10 May 2020).

30. Simó-Gil, N. L'acollida d'alumnat immigrat en el sistema educatiu a Catalunya: Reflexions i propostes a partir de l'anàlisi del cas de Vic. Temps D'educació 2011, 40, 147-162.

31. Erra, M.; Serra, J. Tota la Veritat Sobre Plataforma per Catalunya: L'ultradretà Josep Anglada al Descobert; Ara Llibres: Barcelona, Spain, 2008.

32. Pladevall, A. La il.lustració a Vic: Les Aportacions de Francesc de Veyan i Mola i Llucià Gallissà i Costa; Galerada: Cabrera de Mar, Spain, 2000. 
33. Roma, F.; Ginesta, X. L'Excursionisme a Vic en el primer terç del segle XX: El cas del Centre Excursionista de Vic i la Colla Gurb. Ausa 2006, 22, 437-476.

34. De Miguel, R. La entrevista en profundidad a los emisores y receptores de los medios. In Investigar en Comunicación; Berganza, M.R., Ruiz, J.A., Eds.; McGraw Hill: Madrid, Spain, 2005; pp. 251-263.

35. Rius-Ulldemolins, J. Culture and authenticity in urban regeneration processes: Place branding in central Barcelona. Urban Stud. 2014, 51, 3026-3045. [CrossRef]

36. Del Rio, O.; Velázquez, T. Planificación de la investigación en comunicación: Fases del proceso. In Investigar en Comunicación; Berganza, M.R., Ruiz, J.A., Eds.; McGraw Hill: Madrid, Spain, 2005; pp. 43-76.

37. Corral-Marfil, J.A.; Sabata-Aliberch, A.; Arimany-Serrat, N. Innovación de embutido tradicional a alimento gourmet: Estudio del caso de Casa Riera Ordeix. Espacios 2018, 39, 23.

38. Michael, C.; Sedghi, A. The World Cities with the Most Powerful Brands-Get the Data. The Guardian, 6 May 2014. Available online: https://www.theguardian.com/cities/datablog/2014/may/06/world-cities-mostpowerful-brands-get-the-data (accessed on 8 May 2020).

39. Green, A.; Grace, D.; Perkins, H. City elements propelling city brand meaning-making processes. Mark. Theory 2018, 18, 349-369. [CrossRef]

40. San Eugenio, J.; Ginesta, X.; Compte-Pujol, M.; Frigola-Reig, J. Building a Place Brand on Local Assets: The Case of The Pla de l'Estany Disctrict and Its Rebranding. Sustainability 2019, 11, 3218. [CrossRef]

41. Casulleras, E. La UVic i el Seu Impacte en el Territori; Universitat de Vic-Universitat Central de Catalunya: Vic, Spain, 2018.

42. Corral-Marfil, J.A.; Puigví, S.; Ferrer, L. “Cómo ha ido la feria?” Estimación del impacto económico de acontecimientos turísticos: Tres estudios de caso. Cuad. De Tur. 2009, 24, 9-27.

43. Ashworth, G.; Kavaratzis, M. Towards Effective Brand Management: Branding European Cities and Regions; Edward Elgar: Cheltenham, UK, 2010.

(C) 2020 by the authors. Licensee MDPI, Basel, Switzerland. This article is an open access article distributed under the terms and conditions of the Creative Commons Attribution (CC BY) license (http://creativecommons.org/licenses/by/4.0/). 